\title{
IS REAL DEPRECIATION OR MORE GOVERNMENT DEFICIT EXPANSIONARY? THE CASE OF SLOVENIA
}

Yu Hsing

\section{Abstract}

The purpose of this paper is to examine the impacts of the real exchange rate, the government deficit and other relevant variables on aggregate output in Slovenia. Few of the previous studies have applied the AD/AS model to examine the impacts of major macroeconomic variables on aggregate output. This paper makes contributions to the literature by applying a rigorous model to examine how real GDP is affected by the real exchange rate, fiscal policy and other related variables. The exponential GARCH model is applied in empirical work. The paper finds that real depreciation of the Euro may affect Slovenia's aggregate output positively or negatively and that more central government deficit as a percent of GDP does not affect aggregate output. In addition, Slovenia's aggregate output is positively associated with the real stock price, the real oil price and real total labor cost or wage and is negatively influenced by the real lending rate and the expected inflation rate. Recent real depreciation of the Euro would help Slovenia's aggregate output whereas expansionary fiscal policy would not be effective in stimulating the economy.

Keywords: exchange rates, government deficits, interest rates, stock prices, labor cost

JEL classification: F31, E62

\section{INTRODUCTION}

The Slovenian economy shows strengths and weaknesses. The economic growth rate of $2.9 \%$ in 2015 was higher than the EU average of 2.0\%. Employment grew $0.86 \%$ from 797.792 thousand in 2014 to 804.637 thousand in 2015. The unemployment rate continued to decline from a recent high of $10.1 \%$ in 2013 to a low of $9.0 \%$ in 2015 , which was slightly lower than the average unemployment rate of $9.4 \%$ in the European Union. International trade has improved as evidenced by a trade surplus of 2,031 million Euro in 2015 from a recent trade deficit of 610 million Euro in 2011, suggesting that its export sector became more competitive globally. The negative inflation rate of $-0.8 \%$ in 2015 preserved the value of the Euro and consumer buying power. Holding other factors constant, recent depreciation of the Euro from US\$1.4708 per Euro in 2008 to US\$1.1095 per Euro in 2015 is expected to stimulate exports but raise import costs. The relatively low government bond yield of $1.71 \%$ in 2015 was slightly higher than the EU average of $1.44 \%$ and made the borrowing less costly. The $2.9 \%$ government

Yu Hsing, PhD

Professor of Economics

Department of Management \& Business

Administration

College of Business, Southeastern Louisiana

University

E-mail:yhsing@selu.edu 
budget deficit as a percent of GDP in 2015 met the $3.0 \%$ Maastricht criterion whereas the $81.7 \%$ central government debt as percent of GDP in 2015 was well above the $60 \%$ Maastricht criterion. (Sources of data: The Bank of Slovenia, Eurostat, International Financial Statistics). The International Monetary Fund (2016) provides an assessment of Slovenia's macroeconomic policy and economic performance.

This paper attempts to analyze whether real depreciation of the Euro is expansionary or contractionary for Slovenia. To the author's best knowledge, few of the previous studies have applied the aggregate demand and aggregate supply model to examine the impact of real depreciation of the Euro on aggregate output in Slovenia. Moreover, this is the only study which in its specification takes into account aggregate demand and aggregate supply. Other relevant variables such as the government deficit, the real interest rate, the real stock price, real labor cost, etc. will be considered in the model as well.

The paper is structured in the following manner. The background is described in the second section. Literature review is presented in the third section. The model is presented in the fourth section. The data are described in the fifth section. A discussion of findings and results is presented in the sixth section. Summary and conclusions are made in the last section.

\section{BACKGROUND}

Since the adoption of the Euro in 2007, Slovenia has conducted monetary policy based on the guidelines of the European Central Bank. The Bank of Slovenia relies on the main refinancing operations to provide liquidity to banks, the marginal lending facility to offer banks overnight loans, and the deposit facility for bank to make overnight deposits.

Slovenia pursued a managed floating exchange rate regime during 1991-2001, a crawling band during 2002-2004, joined ERMII during 2005-2006, and has adopted the Euro since 2007. As the European Central Bank adopts a free floating exchange rate system, significant depreciation or appreciation of the Euro is expected to affect Slovenia's exports, imports, domestic prices, inflation, and international capital flows.

Generous pensions, preferential tax treatment of pensions, early retirement age, rising healthcare costs, lack of a broad-based property tax, the high cost of recapitalization of state-owned banks, continuing budget deficits, etc. have increased government debt fourfold during 2008-2015. Fiscal adjustment programs are needed to reduce rapidly rising government debt.

The slow process of privatization of state-owned enterprises, a high financial leverage of small and medium enterprises, low interest margins, low lending volume, slow process of the reduction of bank nonperforming loans are expected to slow economic growth and increase financial instability. (International Monetary Fund 2016)

\section{LITERATURE REVIEW}

There have been major studies of the impacts of the exchange rate, fiscal policy and other relevant variables on aggregate output for Slovenia. Hsing (2009) reveals that real depreciation causes the trade balance in Slovenia to deteriorate in the short run and long run and that there is lack of support for a J-curve in Slovenia. Audzei and Brázdik (2015) find that the contribution of real exchange rate shocks to output in Slovenia is $12 \%$ in the short run and $15 \%$ in the long run and that the real exchange rate can be regarded as a shock-absorbing factor. Stavárek and Miglietti (2015) show that the real effective exchange rate and output in Slovenia have a weak correlation and that the role of the exchange rate in explaining the variation in economic fundamentals may be limited.

Josheski and Eftimoski (2016) report that real appreciation raises output. Hence, real depreciation is contractionary and is not recommended. In addition, more world output, a lower world interest rate, a lower inflation rate raises output whereas the coefficient of government spending as a percent of GDP is insignificant, suggesting the Ricardian equivalence hypothesis may be valid.

Karadam and Özmen (2016) indicate that real depreciation is contractionary for developing countries with high external debt and expansionary for advanced countries and that a high degree of trade openness strengthens the contractionary impact of real depreciation.

Kramolišová and Spáčilová (2015) find a strong negative relationship between the growth rate and the debt-to-GDP ratio for 27 EU countries during 2001-2007. Combes, Minea, Mustea and Yogo (2016) find that government spending multipliers are positive but relatively low, vary across countries, and are sensitive to other factors such as fiscal standing, exchange rate regimes, the stage of economic development, and the degree of openness. Gyódi (2016) shows that sovereign debt risk affects macroeconomic variables significantly, that sovereign credit ratings affect government bond yields significantly, and that there was regional contagion during the debt or financial crisis. Papaioannou (2016) indicates that more government spending has a significant positive 
impact on economic growth if the real interest rate is negative. Globan and Matošec (2016) argue that stimulating economic growth is a better way to solve the high debt-to-GDP problem and that a country would pay a high price for unsustainable public debt. Bökemeier and Stoian (2016) examine the debt ratios for 10 CEEC countries during 1997-2013. For Slovenia, the current debt ratio was below the sustainable debt ratio, but the gap became small due to the increase the debt ratio after the global financial crisis. They also find that the debt-to-GDP ratios in 2015 for Bulgaria and Romania were not sustainable whereas the other 8 countries had sustainable debt-to-GDP ratios.

\section{THEMODEL}

The aggregate demand and aggregate supply model is a major macroeconomic tool to analyze the potential impact of a change in one of the exogenous variables such as the exchange rate, fiscal policy, supply shocks, etc. on the equilibrium real GDP (Romer 2000; Mishkin 2012; Hubbard, O'brien, and Rafferty 2014). The exogenous variables considered are determined by economic theory, country economic conditions, data availability, and other factors. We specify that aggregate demand in Slovenia is determined by the inflation rate, government spending, government tax revenue, the real interest rate, the real stock price, and the real effective exchange rate and that shortrun aggregate supply is a function of the inflation rate, the real oil price, real total labor cost and the expected inflation rate. We can express the aggregate demand and short-run aggregate supply functions as:

$$
\begin{aligned}
Y^{d} & =f(\pi, G, T, R, S, \varepsilon) \\
Y^{s} & =h\left(\pi, E, W, \pi^{e}\right)
\end{aligned}
$$

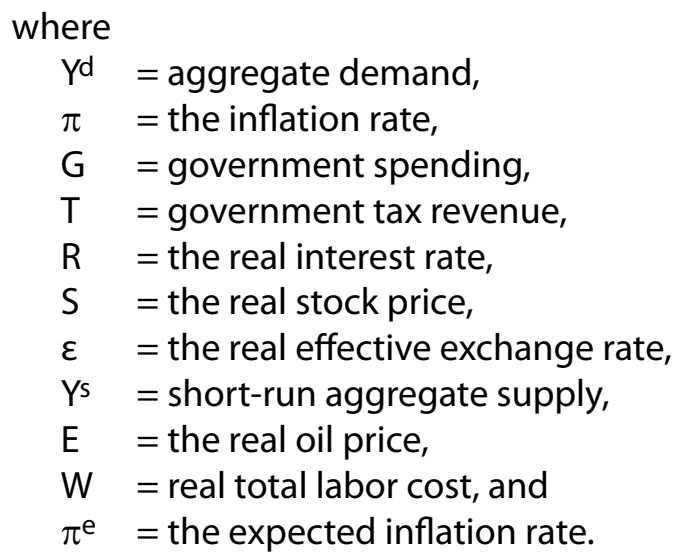

In equilibrium, $Y^{d}=Y^{s}$. Solving for the two endogenous variables, $Y$ and $\pi$, we have the equilibrium real GDP:

$$
\bar{Y}=w\left(\varepsilon, G-T, R, S, E, W, \pi^{e}\right)
$$

The sign beneath each of the exogenous variables shows the impact of a change in the exogenous variable on the equilibrium real GDP. We expect that the equilibrium real GDP has a positive relationship with the real stock price, a negative relationship with the real interest rate and the expected inflation rate and an unclear relationship with the real effective exchange rate, the government deficit, the real oil price and the real total labor cost.

Whether real exchange rate depreciation would increase or reduce aggregate output has been investigated extensively. Real depreciation tends to make domestic-made goods and services cheaper and more competitive globally, increase exports, and shift aggregate demand upward. On the other hand, real depreciation tends to make imports more costly, raise domestic inflation, and shift the short-run aggregate supply curve leftward. The net effect of real depreciation on aggregate output is unclear and needs to be found empirically. There have been several studies on the impact of real depreciation on aggregate output in selected Eastern and Southeastern European countries. Mills and Pentecost (2001) show that real appreciation may increase, reduce or not affect real output in different countries in the long run. Mitchell and Pentecost (2001) reveal that devaluations reduce real output in the short run and long run. Miteza (2006) finds that devaluations cause real output to decline in the long run. Bahmani-Oskooee and Kutan (2008) report that real depreciation may increase, reduce or not affect real output in different countries in the short run and has no long-term effect on real output.

Empirical studies on the impact of the government deficit/debt on real output are inconclusive. The Ricardian equivalence hypothesis (Barro 1974, 1989) suggests that the effect of deficit- or debt-financed government spending is neutral in the long run. Feldstein (1982), Hoelscher (1986), Cebula (1997), Cebula and Cuellar (2010), Cebula (2014a, 2014b), Cebula, Angjellari-Dajci, and Foley (2014) and others maintain that more government deficit/debt raises real interest rates and tends to crowd out spending by households and businesses. However, studies by McMillin (1986), Gupta (1989), Darrat (1989, 1990), Findlay (1990), and Ostrosky (1990) argue that more government deficit/debt would not raise the interest rate.

A higher real oil price due to a negative supply shock would shift the short-run aggregate supply 
curve to the left. On the other hand, if a higher real crude oil price is caused by a demand shock, it would shift the aggregate demand curve to the right. Hence, the net impact is uncertain (Hamilton 1996; Kilian 2008a, 2008b).

A higher real labor cost is expected to shift shortrun aggregate supply to the left due to a higher production cost. On the other hand, a higher real total labor cost or wage tends to increase labor productivity, consumption spending, aggregate demand and real GDP. Real wages and output may be pro-cyclical or counter-cyclical. Hence, the sign of real total labor cost is unclear (Abraham and Haltiwanger 1995; Mills and Pentecost 2001; Miteza 2006; Narayan and Smyth 2009; Castle and Hendry 2014; Spencer 2015).

\section{THE DATA}

The data were collected from the Bank of Slovenia, the Eurostat by the European Commission and IMF's International Financial Statistics (2007). Real GDP is measured in million Euro. An increase in the real effective exchange rate means real appreciation, and vice versa. The deficit variable is measured as central government deficit a percent of GDP. The real lending rate is the difference between the nominal lending rate and the expected inflation rate. The real stock price is equal to the equity price adjusted for the consumer price index. Real total labor cost is measured as nominal total labor cost divided by the consumer price index. The expected inflation rate is calculated as the average inflation rate of the past four quarters. Except for the real lending rate, the government deficit as a percent of GDP and the expected inflate rate with negative values, other variables are measured on a log scale. The sample ranges from 2003.Q1 to 2015. Q4. The data for the lending rate are not available before 2003.Q1.

An analysis of the data (Figure 1) shows that the relationship between real GDP and the real effective exchange rate seem to exhibit a positive relationship during 2003.Q1 - 2008.Q3 and a negative relationship during 2008.Q4 - 2015.Q4. Hence, a binary variable is created with a value of one during 2008.Q4 - 2015. Q4 and zero otherwise. An interactive term and an intercept binary variable are added to the estimated regression (Gujarati and Porter 2009). Figure 2 reveals that it is unclear whether real GDP and the government deficit as a percent of GDP display a positive or negative relationship during the sample period.
Figure 1: Scatter Diagram between Real GDP (RGDP) and the Real effective Exchange Rate (REER)

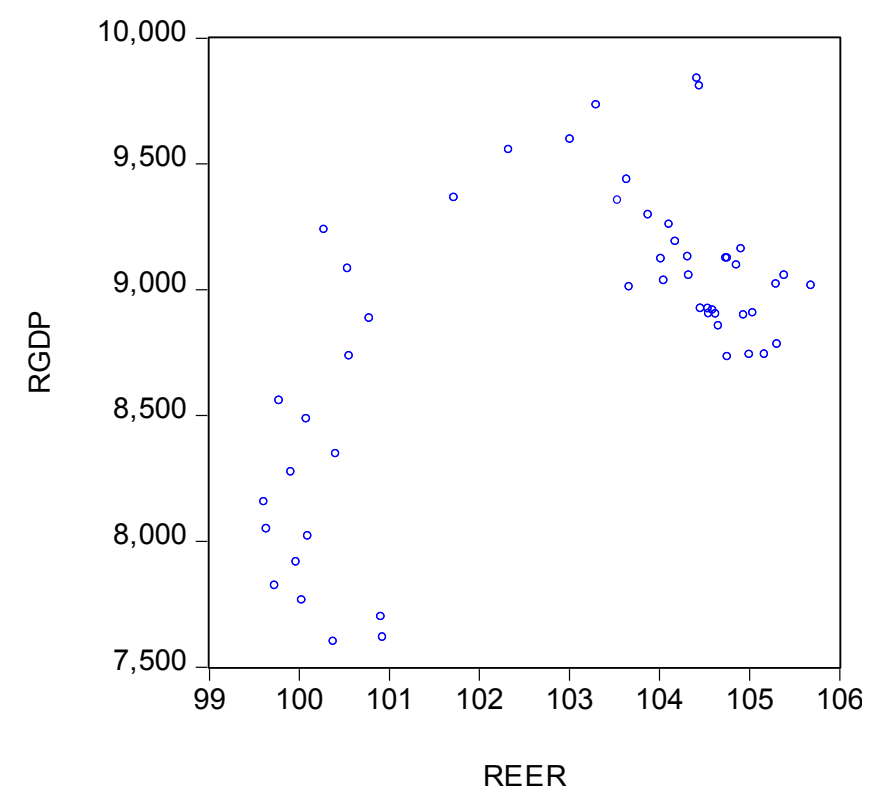

Figure 2: Scatter Diagram between Real GDP (RGDP) and government deficit as a percent of GDP (DEFICITGDP)

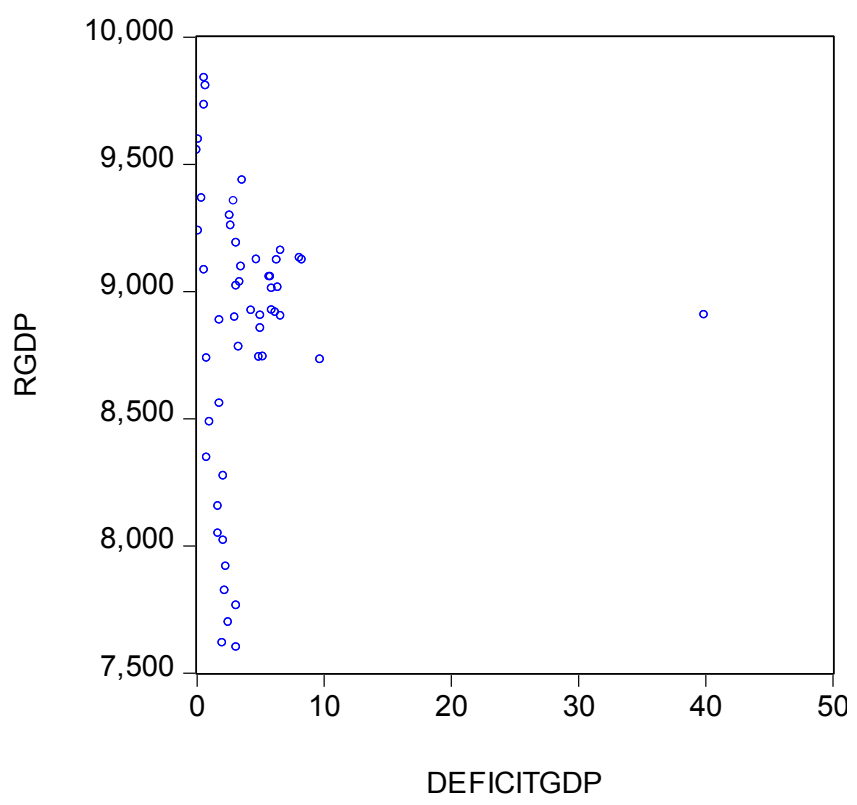

Due to the dynamic relationships between real GDP and the real effective exchange rate in Figure 1, the regression to be estimated is given by:

$$
\bar{Y}=x\left(\varepsilon, \varepsilon \times B, B, G-T, R, S, E, W, \pi^{e}\right)
$$

where $B$ is the binary variable defined above. 


\section{DISCUSSION OF FINDINGS AND RESULTS}

The DF-GLS test on the regression residuals is applied to determine whether these time series variables are cointegrated because cointegration of the residuals suggests that these time series variables have a long-term stable relationship. The DF-GLS test is an augmented Dickey-Fuller (ADF) test except that the time series is transformed via a generalized least squares (GLS) regression before performing the test. Elliott, Rothenberg, and Stock (1996) have shown that this test has significantly greater power than the previous versions of the augmented Dickey-Fuller (ADF) test. In the test equation with the trend and intercept, the value of the test statistic is estimated to be -3.5811, which is greater than the critical value of -2.6111 at the $1 \%$ level in absolute values. Therefore, these time series variables have a long-term stable relationship.

The estimated regression and relevant statistics are reported in Table 1. The EGARCH method is employed to estimate the variance equation and regression parameters. The advantage of EGARCH model is that the parameters in the variance equation have less restrictions. The right-hand side variables can explain approximately $94.57 \%$ of the variation in Slovenia's real GDP. Except that the coefficient of G - T, all other coefficients are significant at the $1 \%$ level. Real GDP in Slovenia has a positive relationship with $\varepsilon$ during 2003.Q1 - 2008.Q3, S, E, and W and a negative relationship with $\varepsilon$ during 2008.Q4 - 2015.Q4, R and $\pi^{e}$. These results suggest that real appreciation of the Euro raised real GDP during 2003.Q1 - 2008.Q3 but reduced real GDP during 2008.Q4 - 2015.Q4. In percent terms and absolute values, $\varepsilon$ during 2003.Q1 - 2008. Q3 has the largest impact. The relatively low mean absolute percent error of $1.0395 \%$ suggests that the estimated regression performs relatively well in forecasting. The relatively low value of the Theil inequality coefficient also implies that the estimated regression fits the sample data relatively well.

If the negative significant coefficient of the real effective exchange rate during 2008.Q4 - 2015.Q4 continues to hold into the future, real depreciation of the

Table 1: Estimated regression of log(real GDP) in Slovenia

\begin{tabular}{|c|c|c|c|}
\hline Variable & Coefficient & z-Statistic & P-value \\
\hline Intercept & -3.781310 & -108.2331 & 0.0000 \\
\hline $\log (\varepsilon)$ & 2.626894 & 797.6275 & 0.0000 \\
\hline $\log (\varepsilon) \times B$ & -5.211625 & -9.673728 & 0.0000 \\
\hline B & 24.20720 & 9.660977 & 0.0000 \\
\hline$(G-T)$ & $-9.18 \mathrm{E}-05$ & -0.384498 & 0.7006 \\
\hline $\mathrm{R}$ & -0.007946 & -3.596307 & 0.0003 \\
\hline $\log (S)$ & 0.073492 & 8.299237 & 0.0000 \\
\hline $\log (E)$ & 0.041185 & 4.591706 & 0.0000 \\
\hline $\log (W)$ & 0.058848 & 3.994484 & 0.0001 \\
\hline$\pi^{e}$ & -0.013156 & -6.832947 & 0.0000 \\
\hline R-squared & \multicolumn{3}{|l|}{0.945720} \\
\hline Adjusted R-squared & \multicolumn{3}{|l|}{0.934088} \\
\hline Akaike info criterion & \multicolumn{3}{|l|}{-5.416691} \\
\hline Schwarz criterion & \multicolumn{3}{|l|}{-4.966404} \\
\hline MAPE & \multicolumn{3}{|l|}{$1.039537 \%$} \\
\hline Theil inequality coefficient & \multicolumn{3}{|l|}{0.008874} \\
\hline Sample period & \multicolumn{3}{|c|}{ 2003.Q1-2015.Q4 } \\
\hline Number of observations & \multicolumn{3}{|c|}{52} \\
\hline Methodology & \multicolumn{3}{|l|}{ EGARCH } \\
\hline
\end{tabular}

Notes: Except for the coefficient of the central government deficit as a percent of GDP,

all other coefficients are significant at the $1 \%$ level.

2.626894 is the estimated slope coefficient during 2003.Q1 - 2008.Q3.

$\mathrm{G}-\mathrm{T}$ : The government deficit is measured as a percent of GDP.

EGARCH stands for the exponential GARCH model.

MAPE is the mean absolute percent error.

The Theil inequality coefficient ranges between 0 and 1 . A value of 0 means perfect fit. 
Euro would reduce Slovenia's aggregate output. The negative and insignificant coefficient of the government deficit as a percent of GDP suggests that a sustainable increase in the government deficit as a percent of GDP may not be harmful to economic growth. The positive significant coefficient of the real stock price shows that an increase in real stock values would raise household wealth, household consumption spending, and real GDP. The positive and significant coefficient of real total labor cost indicates that the positive effect of a higher real labor cost or wage such as higher labor productivity or more consumption spending outweighs the negative effect of a higher real labor cost or wage during the sample period.

In comparison, this paper finds that the real effective exchange rate has significant impacts on real GDP whereas Stavárek and Miglietti (2015) reveal that the correlation of real GDP and the real effective exchange rate is weak. This study shows that the real effective exchange rate may increase or reduce real GDP depending upon the time periods whereas Josheski and Eftimoski (2016) find that real appreciation raises real GDP and that real depreciation is not recommended. This paper finds that government deficit spending is insignificant. Josheski and Eftimoski (2016) also report that the coefficient of government consumption spending is insignificant.

\section{SUMMARY AND CONCLUSIONS}

This paper has examined the effect of real depreciation of the Euro, fiscal policy and other relevant variables on Slovenia's aggregate output based on aggregate demand and aggregate supply analysis. A reduced form equation is estimated by the EGARCH model. Real appreciation of the Euro is found to have different effects on real GDP during different time periods. Real appreciation of the Euro raised real GDP during 2003.Q1 - 2008.Q3 but reduced real GDP during 2008.Q4 - 2015.Q4. Central government deficit as a percent of GDP did not affect real GDP. In addition, a lower real lending rate, a higher real stock price, a higher real oil price, a higher real total labor cost or wages or a lower expected inflation rate is expected to increase real GDP.

There are policy implications. To promote economic growth, the Slovenian government needs to pursue fiscal prudence, hold the real interest rate low, maintain a healthy financial and stock market, and reduce inflation expectations. Different impacts of real appreciation of the Euro before and after 2008.Q4 suggest that the global financial crisis beginning in 2008 may have caused the Euro exchange rate to have a significant structural break on real GDP. The insignificant coefficient of the government deficit as a percent of GDP implies that expansionary fiscal policy may not be an effective macroeconomic tool to stimulate the economy. The Euro exchange rate and the oil price are external factors and need to be monitored closely.

A limitation of the paper is the relatively short sample period of 2003.Q1-2015.Q4. Hence, once new data become available, the regression may need to be re-estimated to determine whether estimated coefficients may change. Future research may consider the impact of labor productivity on real GDP.

\section{REFERENCES}

Abraham, K. G. and Haltiwanger, J. C. 1995. Real wages and the business cycle. Journal of Economic Literature 33(3): 1215-1264.

Audzei, V. and Brázdik, F. 2015. Exchange rate dynamics and its effect on macroeconomic volatility. The Working Paper Series No. 7 of the Czech National Bank (CNB).

Bahmani-Oskooee, M. and Kutan, A. M. 2008. Are devaluations contractionary in emerging economies of Eastern Europe?. Economic Change and Restructuring 41(1): 61-74.

Barro, R. J. 1974. Are government bonds net wealth?. Journal of Political Economy 82(6): 1095-1117.

Barro, R. J. 1989. The Ricardian approach to budget deficits. Journal of Economic Perspectives 3(2): 37-54.

Bökemeier, B. and Stoian, A. M. 2016. Debt sustainability issues in the Central and Eastern European Countries. Bielefeld Working Papers in Economics and Management No. 07-2016, Bielefeld University, Germany.

Castle, J. L. and Hendry, D. F. 2014. The real wage-productivity nexus. VOX CPER's Policy Portal, January 13. .

Cebula, R. J. 1997. An empirical note on the impact of the federal budget deficit on ex ante real long term interest rates, 1973-1995. Southern Economic Journal 63(4): 1094-1099.

Cebula, R. J. 2014a. Impact of federal government budget deficits on the longer-term real interest rate in the US: Evidence using annual and quarterly data, 1960-2013. Applied Economics Quarterly 60(1): 23-40.

Cebula, R. J. 2014b. An empirical investigation into the impact of US federal government budget deficits on the real interest rate yield on intermediate-term treasury issues. 1972-2012. Applied Economics 46(28): 3483-3493.

Cebula, R. J. and Cuellar, P. 2010. Recent evidence on the impact of government budget deficits on the ex ante real interest rate yield on Moody's Baa-rated corporate bonds. Journal of Economics and Finance 34(3): 301-307.

Cebula, R. J., Angjellari-Dajci, F. and Foley, M. 2014. An exploratory empirical inquiry into the impact of federal 
budget deficits on the ex post real interest rate yield on ten year treasury notes over the last half century. Journal of Economics and Finance 38(4): 712-720.

Combes, J. L., Minea, A., Mustea, L. and Yogo, T. 2016. Output effects of fiscal stimulus in Central and Eastern European countries. Post-Communist Economies 28(1): 108-127.

Darrat, A. F. 1989. Fiscal deficits and long-term interest rates: Further evidence from annual data. Southern Economic Journal 56(2): 363-373.

Darrat, A. F. 1990. Structural federal deficits and interest rates: some causality and cointegration tests. Southern Economic Journal 56(3): 752-759.

Elliott, G., Rothenberg, T. J. and Stock, J. H. 1996. Efficient tests for an autoregressive unit root. Econometrica, 64(4): 813-836.

Feldstein, M. 1982. Government deficits and aggregate demand. Journal of Monetary Economics 9(1): 1-20.

Findlay, D. W. 1990. Budget deficits, expected inflation and short-term real interest rates: Evidence for the US. International Economic Journal 4(3): 41-53.

Globan, T. and Matošec, M. 2016. Public debt-to-GDP ratio in new EU member states: Cut the numerator or increase the denominator?. Journal for Economic Forecasting (3): 57-72.

Gyódi, K. 2016. Determinants of government bond yields and contagion during the crises in the CEE countries.

Hamilton, J. D. 1996. This is what happened to the oil price-macroeconomy relationship. Journal of Monetary Economics 38(2): 215-220.

Hoelscher, G. 1986. New evidence on deficits and interest rates. Journal of Money, Credit and Banking 18(1): 1-17.

Hsing, Y. 2009. Test of the J-curve for six selected new EU countries. International Journal of Economic Policy in Emerging Economies 2(1): 76-85.

Hubbard, R. G., O'Brien, A. P. and Rafferty, M. P. 2014. Macroeconomics. NY, New York: Pearson.

International Monetary Fund 2016. Republic of Slovenia: 2016 Article IV consultation-press release and staff report for the Republic of Slovenia. Country Report No. 16/121, May 16.

Josheski, D. and Eftimoski, D. 2016. Application of IS-MP-IA model and Taylor rule to CESEE economies. Economics and Culture 13(1): 5-13.

Karadam, D. Y. and Özmen, E. 2016. Real exchange rates and growth (No. 1609). ERC-Economic Research Center, Middle East Technical University.
Kilian, L. 2008a. The economic effects of energy price shocks. Journal of Economic Literature 46(4): 871-909.

Kilian, L. 2008b. Not all oil price shocks are alike:Disentangling demand and supply shocks in the crude oil market. CEPR Discussion Paper No. 5994.

Kramolišová, V. and Spáčilová, L. 2015. Public debt and economic growth in European Union countries.

Kurečić, P. and Kokotović, F. 2016, January. The EU 2020: Understanding the necessity of maintaining a sustainable fiscal policy. Political Science Forum 5(1): 14-46.

McMillin, W. D. 1986. Federal deficits and short-term interest rates. Journal of Macroeconomics 8(4): 403-422.

Mishkin, F. S. 2012. Macroeconomics: Policy and Practice. Boston, MA: Addison-Wesley

Mills, T. C. and Pentecost, E. J. 2001. The real exchange rate and the output response in four EU accession countries. Emerging Markets Review 2(4): 418-430.

Mitchell, A. and Pentecost, E. J. 2001. The real exchange rate and the output response in four transition economies: $A$ panel data study. In Exchange Rate Policies, Prices and Supply-Side Response, pp. 68-77. Palgrave Macmillan, UK.

Miteza, I. 2006. Devaluation and output in five transition economies: A panel cointegration approach of Poland, Hungary, Czech Republic, Slovakia and Romania, 1993-2000. Applied Econometrics and International Development 6(1): 77-86.

Narayan, P. K. and Smyth, R. 2009. The effect of inflation and real wages on productivity: New evidence from a panel of G7 countries. Applied Economics 41(10): 1285-1291.

Ostrosky, A. L. 1990. Federal government budget deficits and interest rates: Comment. Southern Economic Journal 56(3): 802-803.

Papaioannou, S. 2016. Public spending, monetary policy and growth: Evidence from EU countries.

Romer, D. 2000. Keynesian macroeconomics without the LM curve. The Journal of Economic Perspectives 14(2): 149-169.

Spencer, D. 2015. Higher real wages would raise productivity and boost demand. The London School of Economics and Political Science. http://blogs.Ise.ac.uk/politicsandpolicy/higher-real-wages-for-workers-in-britain-wouldraise-productivity-and-boost-demand/.

Stavárek, D. and Miglietti, C. 2015. Effective exchange rates in central and Eastern European Countries: Cyclicality and relationship with macroeconomic fundamentals. Review of Economic Perspectives 15(2): 157-177. 